\title{
Messages Communication in the Al-Qur'an (Study of Messages in the Al-Qur'an for Believers)
}

\author{
Hasbullah $^{1}$, Muntasir ${ }^{2}$, Saiful Bahri ${ }^{1}$, Riska Zahara ${ }^{3}$, Zulfia $^{3}$ \\ ${ }^{1}$ Lecturer in Islamic Higher Institution Al-Aziziyah Samalanga Bireun Aceh \\ ${ }^{2}$ Lecturer in UNIMAL Lhokseumawe Aceh \\ ${ }^{3}$ Student in Islamic Higher Institution Al-Aziziyah Samalanga Bireun Aceh \\ tgk.hasbuh76@gmail.com
}

\begin{abstract}
Not all of the verses in the Al-Quran that are historical and normative can be understood only textually, because many of the verses in the Al-Quran still have broad (universal) meanings and need to be interpreted deeper, so that a law or wisdom that can be understood and practiced by all humans in general and Muslims in particular. From the peel of this verse several conclusions can be drawn, including namely; Al-Quran is the source of Islamic communication. Because all the elements of Islamic communication are contained in the Al-Quran, among these elements are misage or message. There are so many terms in the Al-Quran that relate to misage of communication. Among them as contained in Surat AtTahrim verse 6; where the message of Islamic communication in the verse is, Allah reminds the believers to protect themselves, their families from the fires of hell. In addition, the message of Islamic communication contained in Surat Al-Baqarah verse 208; the Al-Quran orders every believer to practice the teachings of Islam perfectly. In other words, Muslims must apply Islamic law in every aspect of their lives.
\end{abstract}

Keywords: Al-Qur'an; message; communication; Islam

\section{Introduction}

Al-Quran is a revelation by Allah to the Prophet Muhammad through the Angel Jibreel, to be conveyed to Muslims, and the Al-Qur'an is as a guide and rule of life for Muslims that are historical and normative.

Not all of the verses of the Al-Qur'an that are historical and normative can be understood only textually, because many of the verses of the Al-Qur'an still have broad (universal) meanings and need to be interpreted deeper, so that a law or wisdom that can be understood and practiced by all humans in general and Muslims in particular.

Al-Quran is also a rule that determines the basic attitude of human life, and requires more detailed explanations, because today there are many complex problems, and certainly not the same as the problems that existed at the time of the Prophet Muhammad.

Interpretation Al-Quran which is considered capable of being a solution of the above conditions experienced extraordinary development. The interpreter, armed with his knowledge, develops the method of interpreting Al-Quran on an ongoing basis to supplement deficiencies or anticipate misappropriation or to analyze more deeply the existing interpretations.

The typology of interpretation develops over time in accordance with the demands and contexts of the times, starting from the interpretation of bi al-ma'tsur or historical interpretation developing towards the interpretation of bi al-ra'yi. Interpretation of bi alma'tsur uses texts in interpreting Al-Quran, while tafsir bi al-ra'yi relies more on ijtihad with 
reason. Whereas based on the method it is divided into: tahlili interpretation, maudhu'i interpretation, ijmali interpretation and muqaran interpretation.

As in this paper the author will use the method of interpretation maudhu'i or thematic to discuss the topic of the messages of Al-Quran to believers. Considering that there are so many messages from the Koran towards believers, the writer needs to limit them to two kinds; first, guarding themselves and their families from their fires; second, practicing Islam perfectly.

\section{Discussion}

\subsection{Protecting Yourself and Family from Hell}

People who are successful in the view of Islam are people who get happiness not only in the world, but they also achieve pleasure in the hereafter. In other words, successful people are people who are able to save themselves and their families from the fires of hell. Therefore Allah Almighty commands those who believe to always take care of themselves, their wives, children, and relatives from the fires of hell. As the word of Allah swt:

Meaning: $O$ you who have believed, protect yourselves and your families from a Fire whose fuel is people and stones, over which are [appointed] angels, harsh and severe; they do not disobey Allah in what He commands them but do what they are commanded. (Q.S. At Tahrim 6).

Previously, we need to know that the At-Tahrim above is included in the Madaniyah letter, because this letter was revealed after the Prophet's migration.

The above verse illustrates that da'wah and education must start at home. This verse is aimed at women and men (mother and father) as similar verses (for example verses that command fasting) are also aimed at men and women. This means that both parents are responsible for their children and also their partners as each is responsible for his behavior. Father or mother alone is not enough to create a household that is encompassed by religious values and shaded by harmonious relationships.

\subsection{The context of the Verse (as Bab an Nuzul) Surah At-Tahrim Verse 6}

The author has not found it about the asbab an nuzul verse 6 of surah At Tahrim specifically, but what we find is only the asbab an nuzul surah At Tahrim in general. The background of the letter of At-Tahrim is related to the household life of the Prophet. Where the Prophet peacefully arranged a night's turn with all his wives. When it was night turn for Hapsah, on that night Hapsah asked permission to visit her parents, the Prophet blessed him. After Hapsah returned home to his parents, the Prophet sent a messenger to pick up a slave named Mariah Qibtiyah to the house of Hapsah. Mariah Qibtiyah was a slave given by the King of Egypt, Muqauqas to the Prophet. The Holy Prophet also had intercourse with the slave at the house of Hapsah. Not long after, Hapsah suddenly returned home. When he got home, he saw the door to his house locked, then in a sad state Hapsah waited outside. Feeling 
Hapsah had gone home, then the Holy Prophet with sweaty face then came out, suddenly the Prophet saw Hapsah in a state of sobbing at the door. So when the Prophet asked, why are you crying, Hapsah replied, apparently you gave permission to go home to my parents' house so that you could put other women in my house, so do you have the heart to do this in my house, Rasul. Is not an act like this has dropped my honor, and my right O Messenger. Then the Prophet said, do you not know that Hafsah, this woman is none other than my slave, whom Allah Almighty has allowed me to do. If so, so that you are not angry with me, then I forbid the slave to me. So, this incident is enough for you, don't tell my other wives. However, the next day, Hapsah immediately came to Aisha's house to notify the incident that night. Then Hapsah told me at length, my coming here to tell you Ayesha, that the Messenger of Allah had forbidden her Mariah Qibtiyah, and Allah swt also had fun between us. So that's when this Surat At Tahrim was revealed. ${ }^{1}$

\subsection{Reasonable (Munasabah) Surah At-Tahrim Verse 6}

When viewed from the aspect of munasabah, the above verse has a close relationship with several other verses, including Surat As Shura verse 214. Allah Almighty says:

Meaning: And give a warning to your closest relatives. (Q.S. As Shura 214)

In this Surah As Shura verse 214, Allah Almighty commands to give fearful news about the torments of hell to his close family. In other words, every Muslim is obliged to protect his family from the fires of hell. The meaning of family here is wife, children, and relatives.

Harmony can also be seen in Surah At Thaghabun verses 14 and 15, Allah says:

Meaning: O Believers, Surely among your wives and your children there is an enemy for you. Then be careful of them and if you forgive and do not rebuke and forgive (them), then surely Allah is Forgiving, Most Merciful. (Q.S. At Thaghabun 14).

\section{Allah says:}

Meaning: Surely your wealth and your children are only a trial (for you), and in the sight of Allah is a great reward. (Q.S. At Thaghabun 15.

From Surah At Thaghabun verse 14 above can be understood, basically the presence of wife and children in the middle of the family is a happiness for the household itself. However, children and wives will be disastrous in the afterlife, if a head of family never orders them to be familiar, and also does not prohibit them from evil deeds.

Similarly, what is understood from the next verse is verse 15; how much responsibility to property. Allah will ask about our property, where it was obtained and where the treasure was taken from. And also a very big burden of responsibility towards children that has been

${ }^{1}$ Ahmad SÉwÊy al MÉlÊkÊ, Hasyiyah Al 'Allamah Al SÉwÊy 'Ala Tafsir Al Jalalaini, (Indonesia : Maktabah DÉrul Al 'Ulum), Juz 4, p. 219 
mandated by Allah Almighty for us. So behind that, Allah will give infinite rewards to those who are able to take care of their children from their fires, and will also get great rewards for those who are good at using their property in the path that Allah accepts.

\subsection{Interpretation of Surah At-Tahrim Verse 6}

Ibn Kasir in the book of Tafsir al Quran al 'Adhimnya explained. There are a number of scholars who provide interpretation of the above verse. Among them is Sufyan At Tsury.

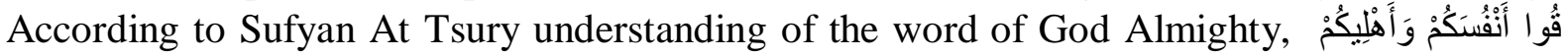
نَارً is teach them manners, and teach them knowledge. He received this interpretation from Mansur; then Mansur received it from a man; then the man received it from 'Ali ra. ${ }^{2}$

Then Bin Ali Bin Abi Talhah states, the understanding of the above verse is as follows: do obey thou to Allah, and stay away from immoral acts to Him, and order your family to remember Allah, then you will surely be kept from hell.

While Mujahid said, the meaning of the above verse is: fear thou God Almighty, and your will be to them by fearing Allah Almighty.

As for the Qatadah, the above verse is: command them to obey Allah, and keep them from immoral acts, and guard them as Allah commands, and command them as Allah commands, and help them in the way of Allah, so when you see them commit immorality, then hold them firm.

The same thing was also conveyed by Ad Dhahak and Maqatil; is an obligation on Muslims to teach the family; slave; and his brother about what God wants to see, and what He forbids. Understanding the meaning of the above verse is in line with the hadith of the Prophet below:

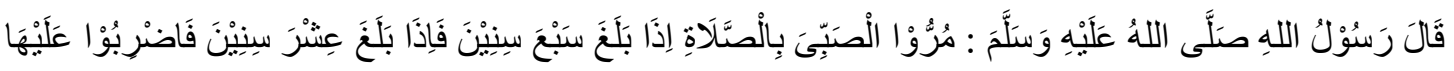

Meaning: Order your children to pray when they reach the age of seven, then beat them when they are ten years old to leave the prayer. (Ahmad, Abu Daud, Turmudhi).

From this verse, it can be understood that a number of very important things are; order to devote to Allah Almighty and preach; the command to save themselves and their families from the fires of hell; how important is Islamic education from an early age; and the command to believe in angels.

The above verse also contains the characteristics of the angels who are pure from sin and never disobey what is commanded by Allah SWT. In contrast to humans and jinn who sometimes obey sometimes also violate some who have never obeyed Allah and His Messenger.

In addition, the above verse also tells how important (urgency) is to educate children from an early age, as illustrated in the hadith of the meaningful Rasulullah SAW:

\footnotetext{
${ }^{2}$ Ibn Kastir, Tafsir Al Quranil 'adhim, (Beirut : DÉrul Ma'rifah), p. 277.
} 
"Every child is born in a state of nature, then only his parents will make him a Jew or a Christian or an Magi." (HR. Bukhari).

\subsection{Practicing Islam with Kaffah (Perfect) and Knowing Satan's Acts}

Islam is derived from the Arabic salima which means "safe, secure and peaceful". Then salima was changed to aslama which meant "surrender to enter into harmony". In addition to the opinion above there are other sources that say that Islam is derived from the Arabic word salima formed into aslamna which means "to keep from being safe, and also to surrender, submit, obey, and obey".

There is also a definition of Islam in terms of religion that teachings revealed by God to humans through the Prophet Muhammad, as an Apostle.

A Muslim is a necessity to apply Islam seriously in all aspects of life, and try to enter into Islam in a kaffah (overall). He must think Islamic, Islamic family, Islamic community and all aspects of his life must be Islamic. Do not mix his life with things that are not Islamic, and do not betray his Islam, either in the presence of beings or in the presence of al-Khaliq far from the sight of His creatures.

Allah says:

O you who have believed, enter into Islam completely [and perfectly] and do not follow the footsteps of Satan. Indeed, he is to you a clear enemy.

(Q.S. Al Baqarah 208).

Surah Al Baqarah was also sent down after the Prophet's migration, therefore Surah Al Baqarah was included in the Madaniyah letter as well. From this verse it can be understood, Allah Almighty commands His servants who believe in Him and justifies His Messenger to hold fast to all the ropes of Islam and His Shari'ah, carry out His commands, and stay away from all prohibitions As much as possible.

Al-'Aufi narrated from Ibn 'Abbas, Mujahid, Thawus, adh-Dhahhak,' Ikrimah, Qatadah, As-Suddi, and Ibn Zaid, about the word of Allah swt about "Enter into Islam", they said, "That is Islam".

As for the word of God, kaaffatan; Ibn 'Abbas, Mujahid, Abul' Aliyah, 'Ikrimah, arRabi' bin Anas, as-Suddi, Muqatil bin Hayyan, Qatadah, and adh-Dhahak said, "Namely jamii'an (whole)". Mujahid said: "That is, do all forms of good deeds." Especially for those who believe from among the People of the Book. As narrated by Abi Hatim from Ibn Abbas, "O you who believe, enter Islam as a whole," he read, namely with Manshub (satiated). their faith in Allah it means that they have adhered to some of the Torah and shari'ah revealed to them. Then Allah said, "Enter ye into Islam as a whole." Allah swt said, "Enter into the shari'ah of the religion of Muhammad and do not leave anything from it, and enough for you to have faith in the Torah and what is contained therein." As for his words "And do not obey the steps of shaytan." Carry out all the deeds of obedience and stay away from what the shaytan has commanded you.Namely those who believe from the People of the Book (Jews and Christians). Because with 


\subsection{Paragraph Context (Asbabun Nuzul Surah Al-Baqarah Verse 208)}

Sabab nuzul this verse according to Imam Al-Baghawi is related to the conversion of Islam to the Jewish Book Expert Bani Nadhir named Abdullah bin Salam and his friends, but after embracing Islam he still considered his glory Saturday and did not want to eat camel meat, then they also stated: "O Messenger of Allah, is not the Torah is the Book of Allah. So let us keep reading it in our evening prayers?" So this verse comes down. This hadith is also mentioned by the author of the book Jalalain in his interpretation and the author of the book Al-Wajiz.

\subsection{Munasabah Surat (Harmony of Surat Al-Baqarah Paragraph 208)}

The author has not found the verses of this verse with other verses, but the author only gets an attachment between the letter with another letter, namely the relationship of Surah alBaqarah to Surah al-Fatihah. At the beginning of Sura al-Baqarah it was written that there is no doubt in it. In the letter al-Fatihah the sentence "show us the straight path," means that when they ask "show us the straight path," Allah answers: the straight path that you ask for is the Koran which has no doubt in it."

\subsection{Interpretation of Surah Al-Baqarah Verse 208}

Ibn Kathir interprets the above verse by stating, Allah Almighty commands His believing servants and trusts His Messenger, to take all the bonds and sharia of Islam, do all His commands and leave all His prohibitions, according to their abilities.

In line with this, Imam An-Nasafi, interpreted that what is meant by the verse is surrender and ta'at, that is surrender and ta'at to Allah swt or Islam. According to him, the word "kaaffah" is haal (explanation of the situation) from dhamir (pronouns) udkhulu (enter you) which means jamii'an (overall / everything, from among the believers). Narrated from Ikrimah, the word of God above was revealed in the case of Tha'labah, 'Abdullah bin Salam, and several other Jews who had converted to Islam. They submitted concessions to the Prophet to be allowed to worship on Saturday, the Jewish holiday (the Sabbath). Then answered by God with the above verse.

Imam Tabari quoted Ikrimah, that the ta'wil verse above is an appeal to the believers to reject all things that are not from Islamic law; carry out all Islamic sharia, and distance themselves from efforts to eliminate something that is part of Islamic law.

Imam Qurthubi explained that lafadz kaaffah is a haal (explanation of the situation) from lafadz al-silmi or from dlomir mu'minin. While the definition of kaaffah is jamii'an (comprehensive) or amatan aamat (general).

If the position of lafadz kaaffah is as a result of lafadz al-silmi, then the interpretation of the verse is that Allah SWT demands those who convert to Islam to enter into Islam as a whole (total). Without any effort to choose or sort out some Islamic law not to be practiced. This understanding is reinforced by sababun nuzul (because of the decline) of the verse which tells the rejection of the dispensation of some Jews when they want to convert to Islam. Of course this kind of thing is not only for people who want to convert to Islam, but also applies 
to believers as explained by Ibn Jarir al-Tabari who quoted the interpretation of Ikrimah above.

\section{Conclusion}

From the above explanation, several conclusions can be drawn, including namely; Al Qur'an also explains clearly, ourselves, our wives, children and families are mandates from Allah; very big responsibility in the hereafter. Therefore for the head of the family, in this case a husband is obliged to free his wife, children and family from the fires of hell.

In addition, the Koran orders every believer to practice the teachings of Islam perfectly. In other words, Muslims must apply Islamic law in every aspect of their lives.

\section{References}

A. Ya'kub Matondang, (1989) Tafsir-Tafsir Ayat-Ayat Kalam Menurut Al-Qadhi Abdul Jabbar, Jakarta : Bulan Bintang.

Al Qaththan, Manna', (2009) MabÉhis FÊ 'Ulum al Quran, dalam Aunur Rafiq El Mazni, Pengantar Studi Ilmu al Quran, Jakarta : Pustaka Al kautsar.

Al-Qurthubi, (2006) Al-Jâmi' li Ahkâm al-Qur'ân wal Mubayyin li Thadhammanuhu minassunnati wa ayil Quran, Beirut: Mu'assisah ar Risalah.

Az Zuhaily, (2010) Wahbah, Kebebasan Dalam Islam, Jakarta : Raja Grafindo.

Az-Zahabi, Muhammad Husain, (2005) at-Tafsir Wal Mufassiruun. Kairo: Darul Hadith.

Az-Zamakhsyari, (1998) Al-Kasysyâf an Haqaiq Ghawamidhit Tanzil wa Uyunil Aqawil fi Wujuhi Ta'wil, Riyad : Maktabah al 'Abikan.

Bin Muhammad Bin Ibrahim, Ali, Tafsir Khadhin; al Mussama Lubab al Takwil fi Ma'ani al Tanzil, Beirut : DÉrul Ma'rifah, tt.

Departemen Agama RI, (2004) Al-Quran dan Terjemahnya, Surabaya : Mekar.

DJalal, Abdul (2004) Ulumul Quran, Surabaya : Dunia Ilmu.

Hasbi Ash Shiddiqie, Muhammad, (2002) Ilmu-Ilmu Al Quran, Semarang : Pustaka Rizki Putra.

Ibn Katsir, Tafsir Al Quranil 'adhim, Beirut : DÉrul Ma'rifah, tt.

Saiful Bahri, (2018) Hadiths About Communication Ethics (Study of Hadiths about Responsibility and Maintaining Information Accuracy), Budapest International Research and Critics Institute-Journal

Saiful Bahri, (2019) Syarkawi Syarkawi, Mursal Mursal, Fizazuawil Fizazuawil, Maimun Maimun, Trust Giving Transactions on Mu'amalah Al-Wadi'ah, Budapest International Research and Critics Institute-Journal (BIRCI-Journal)

Sawi, Ahmad, HÉsyiyah Al 'Allamah As ShÉwi 'ala Tafsir Jalalain, Indonesia; Maktabah Darul 'Ulum, tt.

Syadali, Ahmad, (2000) Ulumul Quran, Bandung : Pustaka Setia.

Yusuf, (2007) Al-Qaradhawi Khitabuna Al-Islammi fi Ashr Al-Aulamah, dalam M. Abdillah Noor, Retorika Islam, Bagaimana Seharusnya Menampilakan Wajah Islam, Jakarta: Pustaka Al-Kautsar. 